\title{
PENGARUH MEDIA PERMAINAN TEKA-TEKI SILANG TERHADAP HASIL BELAJAR SISWA PADA PEMBELAJARAN GEOGRAFI DI SMA NEGERI 1 MARISA
}

\author{
Sarjon Lakoro ${ }^{\mathrm{a}}$, Sunarty Eraku ${ }^{\mathrm{b}}$, Daud Yusuf ${ }^{\mathrm{c}}$ \\ ${ }^{a}$ Jurusan Ilmu dan Teknologi Kebumian, Fakultas Matematika dan Ilmu Pengetahuan Alam, Universitas Negeri \\ Gorontalo Jln. Jenderal Sudirman, Kota Gorontalo 96128, Indonesia
}

INFO ARTIKEL
Status artikel:
Diterima: 03-03-2020
Disetujui: 04-03-2020
Tersedia online:04-03-2020
Kata kunci:
Media Teka Teki; Hasil Belajar;
Pembelajaran Geografi
Penulis korespondensi:
Sarjon Lakoro
Jurusan Ilmu dan Teknologi Kebumian,
Kota Gorontalo 96128, Indonesia
Email:
sarjonlakoro97@ gmail.com
DOI: $10.34312 /$ jgej.v1i1.4845

Copyright @ 2020 JGEJ-UNG

All Rights Reserved.

\begin{abstract}
The Effect of Crossword Puzzle Game Media on Students' Learning Outcomes in Geography Learning (A Case Study at Grade X IPS at Senior High School of SMAN 1 Marisa). This experimental study is about learning outcomes which aimed to determine significant differences in students' learning outcomes using crossword media and Powerpoint media. This employed a quantitative approach where the design forms use a posttest-only control group design. In this method, we will see how the cause and effect relationships of using treatments use crosswords and PowerPoint media. In collecting data, learning test results are used in the study sample. The sample is two classes of X IPS as an experimental class with a control class, namely class X IPS 1 consisting of 32 students as an experimental class and class X IPS 3 consisting of 31 students as a control class. To take samples, the researcher used a Clauster random sampling technique or random sampling group. Based on the results of data analysis, it was found that there was a significant difference on the learning outcomes of students who were taught using media crosswords with learning outcomes of students who were taught using powerpoint media. This is indicated by the results of the t-test. Furthermore, the value of $t$ is $t$ count $=4,57$ and $t$ table $=1,99$. The sample is stated to be significantly different if $t$ count $>t$ table. Hypothesis test results show that $\mathrm{t}$ count $>\mathrm{t}$ table is $4,57>1,99$. Therefore, it can be concluded that from the t-test results $\mathrm{H}_{0}$ is rejected and $\mathrm{H}_{\mathrm{I}}$ is accepted. In other words, it has a significant difference
\end{abstract}

\begin{abstract}
ABSTRAK
Pengaruh Media Permainan Teka-Teki Silang pada Hasil Belajar Siswa dalam Pembelajaran Geografi (Studi Kasus di Kelas X IPS di SMA Negeri 1 Marisa). Penelitian eksperimental ini adalah tentang hasil belajar yang bertujuan untuk menentukan perbedaan yang signifikan dalam hasil belajar siswa menggunakan media teka-teki silang dan media Powerpoint. Ini menggunakan pendekatan kuantitatif di mana bentuk desain menggunakan desain kelompok kontrol posttest-only. Dalam metode ini, kita akan melihat bagaimana hubungan sebab dan akibat menggunakan perawatan menggunakan teka-teki silang dan media PowerPoint. Dalam mengumpulkan data, hasil tes pembelajaran digunakan dalam sampel penelitian. Sampel adalah dua kelas X IPS sebagai kelas eksperimen dengan kelas kontrol, yaitu kelas X IPS 1 yang terdiri dari 32 siswa sebagai kelas eksperimen dan kelas X IPS 3 yang terdiri dari 31 siswa sebagai kelas kontrol. Untuk mengambil sampel, peneliti menggunakan teknik sampel acak Clauster atau kelompok sampel acak. Berdasarkan hasil analisis data, ditemukan bahwa terdapat perbedaan yang signifikan pada hasil belajar siswa yang diajar menggunakan media tekateki silang dengan hasil belajar siswa yang diajar menggunakan media powerpoint. Ini ditunjukkan oleh hasil uji-t. Selanjutnya, nilai t hitung $=4,57$ dan $\mathrm{t}$ tabel $=1,99$. Sampel dinyatakan berbeda secara signifikan jika $t$ hitung $>\mathrm{t}$ tabel. Hasil uji hipotesis menunjukkan bahwa thitung> ttabel adalah 4,57> 1,99. Oleh karena itu, dapat disimpulkan bahwa dari hasil uji-t H0 ditolak dan HI diterima. Dengan kata lain, ia memiliki perbedaan yang signifikan
\end{abstract}




\section{Pendahuluan}

Guru dituntut untuk selalu kreatif dalam penggunaan media pembelajaran. Oleh sebab itu perlu adanya media dan metode pendidikan yang bisa mengembangkan potensi para peserta didik. Penggunaan media dan sarana dalam proses pembelajaran akan memberikan stimulus yang bisa membantu dalam pembelajaran, (Somara,dkk. 2013:130). Salah satu hal yang dapat dilihat dari proses pembelajaran yang tidak efektif adalah Rendahnya hasil belajar siswa khususnya pembelajaran geografi. Tentunya, upaya yang dilakukan untuk mencapai tujuan yang telah ditetapkan maka peran guru sangat dibutuhkan. Peran ini diharapkan dapat membuat atmosfer dalam kegiatan pembelajaran dapat menyenangkan, (Wasgito dan Setiadarma, 2014).

Kegiatan pembelajaran yang kurang aktif dapat disebabkan oleh beberapa faktor. Salah satunya adalah penggunaan media yang kurang tepat, (Khalillah, 2012). Berdasarkan hasil wawancara dan observasi yang dilakukan terhadap salah satu guru geografi di SMA Negeri 1 Marisa menyatakan bahwa metode pembelajaran yang biasa digunakan selama proses pembelajaran Geografi berlangsung, sebagian besar masih menggunakan metode ceramah, diskusi kelompok dengan penggunaan media buku paket, slide power point menggunakan LCD dalam mengajar dimana penggunaan media tersebut sebenarnya cukup baik, namun sudah umum digunakan selama proses pembelajaran di beberapa sekolah. Penggunaan strategi dapat menjadi penyebab rendahnya mutu yang diharapkan, (Zulfajri dan Amelia, 2016). Guru diharapkan bisa menggunakan alat-alat yang tersedia di Sekolah. Tuntutan Guru profesional dalam penggunaan berbagai macam media pembelajaran sangat besar. Dengan kemajuan teknologi, berbagai macam media dapat digunakan. Tidak hanya mengandalkan media berbasis power point tetapi dapat mengandalkan media berupa permainan edukatif, salah satunya yaitu media permainan teka-teki silang, (Witdawati, 2016).

Teka-teki silang atau biasa disebut, TTS merupakan permainan klasik. TTS akan memberikan pengaruh dalam kemampuan otak dan pengetahuan. Menjadikan peserta didik aktif, menyenangkan, memunculkan semangat belajar, menumbuhkan rasa kreatifitas peserta didik, mengasah daya ingat peserta didik, media tersebut dapat digunakan di tempat manapun tanpa ada penyesuaian khusus, serta dapat digunakan dalam kelompok besar dan kelompok kecil. Penggunaan media pembelajaran teka teki silang ini memiliki banyak keunggulan dalam proses pembelajaran. Penggunaan media teka-teki silang sebagai media visual dapat meningkatkan daya ingat siswa,menumbuhkan rasa kreatifitas peserta didik, meningkatkan antusias belajar, serta membuat proses belajar lebih menyenangkan.

Penggunaan media TTS memberikan banyak keunggulan kepada peserta didik dalam proses pembelajaran. Diantaranya adalah dapat meningkatkan motivasi siswa dalam menjawab soal, memberikan stimulus agar peserta diidk berpikir kritis dan kreatif, (Fathonah, 2013). Selain itu Permainan TTS merupakan kegiatan bermain yang dapat mengasah otak, (Setiawan dan Zuhdi, 2019). Penggunaan media ysng memuat permainan edukatif sangat jarang diterapkan di sekolah tersebut seperti media teka-teki silang. Untuk itu berdasarkan uraian di atas, peneliti menerapkan media berupa teka teki silang pada mata pembelajaran geografi, yang mana peneliti mengangkat penelitian ini dengan judul "Pengaruh media permainan teka teki silang terhadap hasil belajar siswa pada pembelajaran geografi Kelas X IPS di SMA Negeri 1 Marisa. Penelitian yang akan dilakukan peneliti adalah penelitian eksperimen. Penelitian eksperimen berbeda dengan Penelitian Tindakan Kelas. Menurut Sugiyono (2012: 109) Penelitian eksperimen dapat diartikan sebagai metode penelitian yang digunakan untuk mencari, pengaruh perlakuan tertentu terhadap yang lain dalam kondisi yang terkendalikan. Sumadoyo (2013: 20) pembelajaran dalam kegiatan kelas dengan tantangan guru dalam memperbaiki kualitas dan hasil pembelajaran. Tujuan penelitian ini adalah untuk mengetahui perbedaan hasil belajar geografi antara Siswa yang diajar dengan menggunakan media permainan teka-teki silang dibandingkan dengan Siswa yang diajar yaitu menggunakan media power point pada tahun ajaran 2019/2020.

\section{Metodologi}

\subsection{Lokasi dan Waktu Penelitian}

Penelitian ini dilaksanakan di SMA Negeri 1 Marisa, Jl. Trans Sulawesi No.20 Kec. Marisa, Kab. Pohuwato, Provinsi Gorontalo. Penelitian ini dilakukan dalam kurun waktu \pm 6 bulan pada pembelajaran semester genap tahun ajaran 2019/2020.

\subsection{Metode Penelitian}

Metode yang digunakan dalam penelitian ini adalah metode eksperimen dengan pendekatan kuantitatif. Dalam metode ini akan dilihat bagaimana hubungan sebab akibat dari penggunaan perlakuan pada kelas yang 
menggunakan media permainan Teka-teki Silang dan kelas yang menggunakan media Power Point, oleh karena itu bentuk desain yang digunakan yaitu (posttest-only control group design). Dalam desain ini dimana terdapat dua kelompok yang masing masing dipilih secara random. Kelompok pertama diberikan perlakuan (X) dan kelompok lain tidak. Kelompok yang diberi perlakuan disebut kelompok experimen dan kelompok yang tidak diberi perlakuan disebut kelompok kontrol, (Sugiyono, 2012 ).

Keterangan:

\begin{tabular}{lll}
\hline Kelas & Perlakuan & Post test \\
\hline Eksperimen & $\mathrm{X}_{1}$ & $\mathrm{O}_{1}$ \\
\hline Kontrol & $\mathrm{X}_{2}$ & $\mathrm{O}_{2}$ \\
\hline
\end{tabular}

$\mathrm{X}_{\mathrm{I}}$ : Pembelajaran dengan menggunakan media permainan teka-teki silang

$\mathrm{X}_{2}$ : Pembelajaran dengan menggunakan media power point

$\mathrm{O}_{1}$ : (Post test) untuk kelas eksperimen

$\mathrm{O}_{2}$ : (Post test) untuk kelas control

Variabel bebas dalam penelitian ini berupa perlakuan pembelajaran. Definisi operasional variabel bebas adalah perlakuan pembelajaran yang diberikan pada kelas eksperimen yang berupa media pembelajaran tekateki silang dan kelas kontrol diberikan perlakuan medial pembelajarn power point. Definisi konseptual variabel bebas perlakuan pembelajaran berupa media pembelajaran teka-teki silang dan perlakuan pembelajaran berupa model pembelajaran power point. Variabel terikat dalam penelitian ini yakni hasil belajar siswa berdasarkan taksonomi Bloom yang di definisikan sebagai tingkat pencapaian atau ketuntasan belajar siswa terhadap materi atau pelajaran yang telah diberikan yang terdiri dari pengetahuan, pemahaman aplikasi dan analisis. Dalam penelitian ini yang menjadi variabel terikat adalah hasil belajar siswa pada materi geografi untuk siswa kelas X IPS SMA Negeri 1 Marisa.

Subyek penelitian adalah dua kelas X IPS yang dijadikan sebagai kelas eksperimen dengan kelas kontrol yaitu kelas X IPS 1 yang terdiri dari 32 siswa sebagai kelas eksperimen dan kelas X IPS 3 yang terdiri dari 31 siswa sebagai kelas kontrol. Dalam pengambilan sampel ini peneliti menggunakan teknik clauster random sampling (sampling acak berkelompok) dengan pertimbangan siswa mendapatkan materi berdasarkan kurikulum yang sama, siswa diajar oleh guru yang sama, dan pembagian kelas tidak ada yang unggulan.

Data yang digunakan dalam penelitian ini menggunakan instrument tes. Dalam melakukan penelitian yang dilakukan pada dua kelas yakni kelas eksperimen dan kelas kontrol maka diperlukan uji reliabilitas tes. Adapun pengujian reliabilitas tes ini menggunakan rumus Alpha Cronbach dengan kriteria penguji jika $\mathrm{r}_{\text {hitung }}$ $>r_{\text {tabel }}$ dengan tafar signifikansi 0,05 maka alat ukur tersebut tidak reliabel, begitu pula sebaliknya jika $\mathrm{r}_{\text {hitung }}<$ $\mathrm{r}_{\text {tabel }}$ maka alat ukur tersebut tidak reliabel.

Penelitian ini dilakukan di dua kelas yaitu kelas eksperimen yang menggunakan media permainan teka-teki silang dan kelas kontrol yang menggunkan media power point. Tahap awal yang dilakukan sebelum melakukan penelitian adalah mempersiapkan instrumen. penelitian yang digunakan dalam pengumpulan data, yaitu tes hasil belajar siswa. Bentuk soal yang digunakan adalah soal pilihan ganda. Sebelum digunakan pada penelitian, terlebih dahulu tes divalidasi oleh validator untuk mengetahui apakah tes tersebut layak untuk digunakan mengukur hasil belajar siswa atau tidak.

Dari uraian diatas maka untuk menentukan validitas suatu instrumen semisal tes hasil pilihan ganda dengan melihat korelasi item soal dalam penelitian ini digunakanlah rumus Korelasi Biseral Point. Adapun kriteria pengujiannya apabila $r_{\text {hitung }}>r_{\text {tabel }}$ dengan taraf signifikan 0,05 maka alat ukur tersebut dinyatakan valid dan sebaliknya jika $r_{\text {hitung }}<r_{\text {tabel }}$ maka alat ukur tersebut tidak valid.

\subsection{Teknik Analisis Data}

\section{a. Uji Normalitas Data}

Pengujian normalitas data digunakan untuk mngetahui apakah data yang diperoleh peneliti berdistribusi normal atau tidak. Dalam penelitian ini pengolahan uji normalitas menggunakan uji Lilliefors. Hipotesis statistik yang di uji dinyatakan sebagai berikut :

$\mathrm{H}_{0}$ : Data berdistribusi normal

$\mathrm{H}_{1}$ : Data tidak berdistribusi normal 
Berdasarkan perhitungan chi kuadrat menunjukan bahwa x 2 hitung $\leq \mathrm{x} 2$ tabel yaitu 8,511 $\leq 11,070$ untuk kelas eksperimen dan $6,747 \leq 11,070$ untuk kelas control, maka dapat disimpulkan bahwa data dari pada tes hasil belajar siswa untuk kelas eksperimen dan kelas control terdistribusi normal.

Pengujian homogenitas varians ini bertujuan untuk mengetahui keseragaman kelas eksperimen dan kelas kontrol yang dijadikan sebagai objek penilaian. Pengujian homogenitas varians ini diuji dengan menggunakan uji Fisher. Adapun kriteria pengujiannya apabila $\mathrm{F}_{\text {hitung }}<\mathrm{F}_{\text {tabel }}$ maka data dinyatakan homogeny dan Jika $\mathrm{F}_{\text {hitung }}$ $>\mathrm{F}_{\text {tabel }}$ maka data dinyatakan tidak homogeny. Berdasarkan perhitungan diatas diperoleh $\mathrm{F}_{\text {hitung }}=1,79$ dan Ftabel 1,82 sehingga dapat dinyatakan $\mathrm{F}_{\text {hitung }}<\mathrm{F}_{\text {tabel }}$ yaitu $1,79<1,82$, maka dapat disimpulkan bahwa kedua sampel dikatakan homogen

Setelah dinyatakan data terdistribusi normal dan homogeny maka dapat dilanjutkan untuk uji hipotesis. Uji hipotesis dilakukan untuk mengetahui apakah terdapat perbedaan yang signifikan antara kelas eksperimen dengan kelas control. Karena kedua data berdistribusi normal dan homogeny, maka uji statistic yang digunakan adalah uji t pada taraf signifikan $\alpha=0,05$. Berdasarkan hasil perhitungan diperoleh thitung $=4,57$ dan $\mathrm{t}_{\text {tabel }}=1$.99. Sampel dikatakan terdapat perbedaan yang signifikan apabila thitung $>$ ttabel. Hasil uji hipotesis menununjukan bahwa $t_{\text {hitung }}>\mathrm{t}_{\text {tabel }}$ yaitu 4,57 $>1.99$, terdapat perbedaan signifikan antara hasil belajar siswa yang diajar menggunakan media permainan teka-teki silang dengan hasil belajar siswa dengan menggunakan media power point.

\section{Hasil dan Pembahasan}

\subsection{Hasil Penelitian}

Penelitian mengenai hasil belajar siswa ini dilaksanakan di SMA Negeri 1 Marisa, Kec. Marisa, Kab. Pohuwato. Penetapan penelitian ini didasarkan pada pertimbangan bahwa penerapan media permainan tekateki silang kurang berkembang dengan baik sehingga perlu dikaji melalui penelitian ilmiah. Subjek penelitian ini terdiri dari kelas eksperimen dengan kelas kontrol yaitu kelas X IPS 1 yang terdiri dari 32 siswa sebagai kelas eksperimen dengan menggunakan media permainan Teka - teki silang dan kelas X IPS 3 yang terdiri dari 31 siswa sebagai kelas kontrol, menggunakan media Power point. Dalam pengambilan subjek ini peneliti menggunakan teknik clauster random sampling (sampling acak berkelompok) dengan pertimbangan siswa mendapatkan materi berdasarkan kurikulum yang sama dan siswa diajar oleh guru yang sama.

Sebelum diberikan tes dari pada hasil belajar, Instrumen penelitian tersebut sebelumnya telah diujicobakan validitas dan reliabilitas. Semua item tes yang telah disusun diuji cobakan kepada 30 responden dengan jumlah soal sebanyak 30 butir soal, jumlah soal yang dinyatakan valid sebanyak 25 butir soal, dengan reliabilitas soal sebesar 0,844 . Kemudian soal yang memenuhi kriteria valid dan mempunyai koefisien reliabilitas yang tes tinggi digunakan sebagai tes hasil belajar siswa baik pada kelompok eksperimen maupun pada kelompok pembanding. Untuk jawaban yang benar diberi nilai satu dan untuk jawaban yang salah diberi nilai nol.

Berdasarkan hasil tes belajar yang diberikan kepada siswa di akhir pembelajaran, diperoleh dua kelompok nilai yaitu kelompok nilai eksperimen dan kelompok nilai kontrol. Kelompok nilai eksperimen adalah skor tes hasil belajar siswa menggunakan media teka-teki silang, sedangkan kelompok nilai kontrol adalah skor tes hasil belajar siswa menggunaan media Power point. Berikut merupakan perbedaan hasil belajar siswa kelas eksperimen dengan kelas kontrol yang dapat dilihat pada gambar dibawah ini.

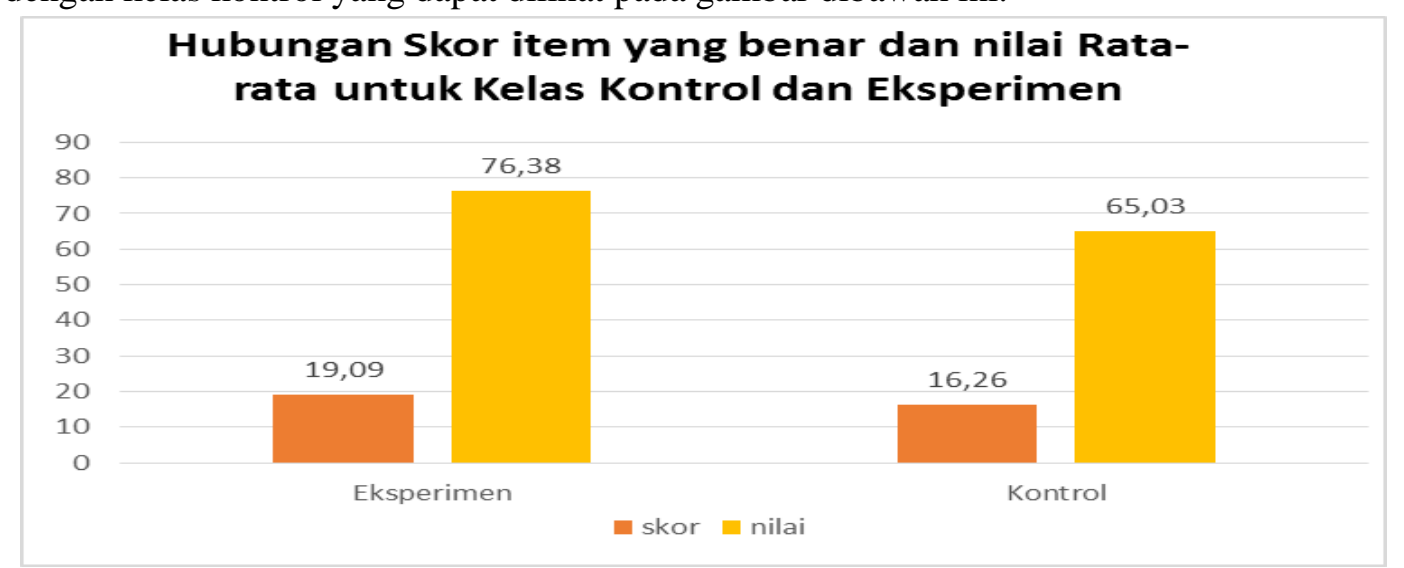

Gambar 1. Skor item yang benar dan nilai hasil belajar siswa kelas eksperimen dan kontrol 
Berdasarkan gambar 1 dapat diketahui bahwa rata-rata skor untuk kelas eksperimen sebesar 19,09 dengn rata-rata nilai hasil belajar siswa kelas eksperimen sebesar 76,38. Nilai tersebut diperoleh dari hasil pelaksanaan tes hasil belajar siswa untuk kelas eksperimen yang diberikan perlakuan dengan menggunakan media permainan teka-teki silang, sedangkan dapat diketahui pula rata-rata skor untuk kelas kontrol sebesar 16,26 dengan nilai rata-rata hasil belajar siswa sebesar 65,03, sehingga dapat disimpulkan bahwa data diatas menunjukan rata-rata hasil belajar siswa kelas eksperimen dengan menggunakan media permainan teka-teki silang lebih tinggi dibandingkan rata rata hasil belajar siswa kelas kontrol yang menggunakan media power point.

\section{1) Kelas Eksperimen}

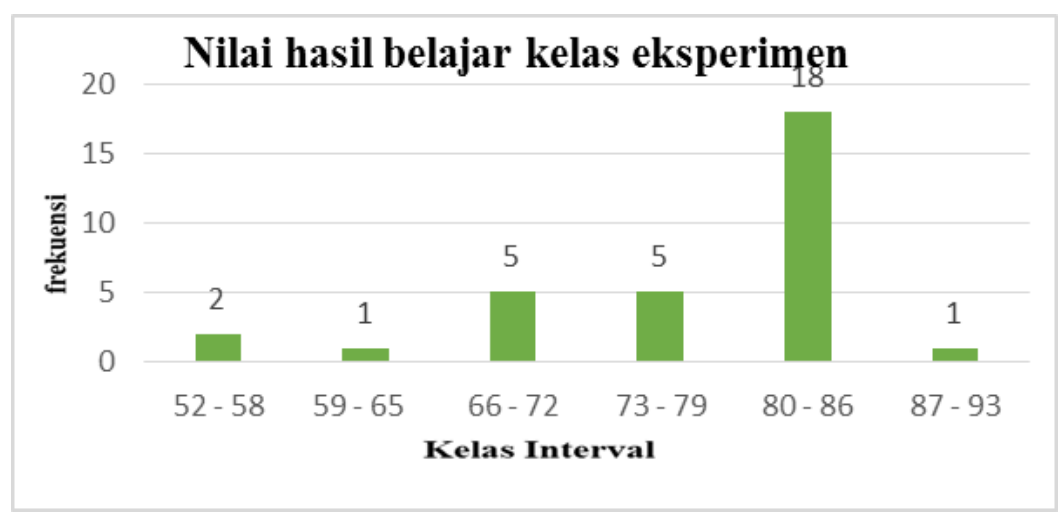

Gambar 2 Distribusi frekuensi kelas eksperimen.

Berdasarkan gambar 2 menunjukan bahwa terdapat satu orang siswa yang memperoleh skor tertinggi pada rentang (87 - 93), sebanyak 18 siswa memperoleh skor hasil belajar pada rentang (80-86), 5 orang siswa memperoleh skor hasil belajar pada interval $(73$ - 79), 5 siswa lainnya memperoleh skor hasil belajar pada rentang (66 - 72), 1 Orang siswa memperoleh skor hasil belajar pada rentang (59-65) dan terdapat 2 orang siswa lainnya yang memperoleh skor terendah yaitu pada rentang $(52-58)$.

\section{2) Kelas Kontrol}

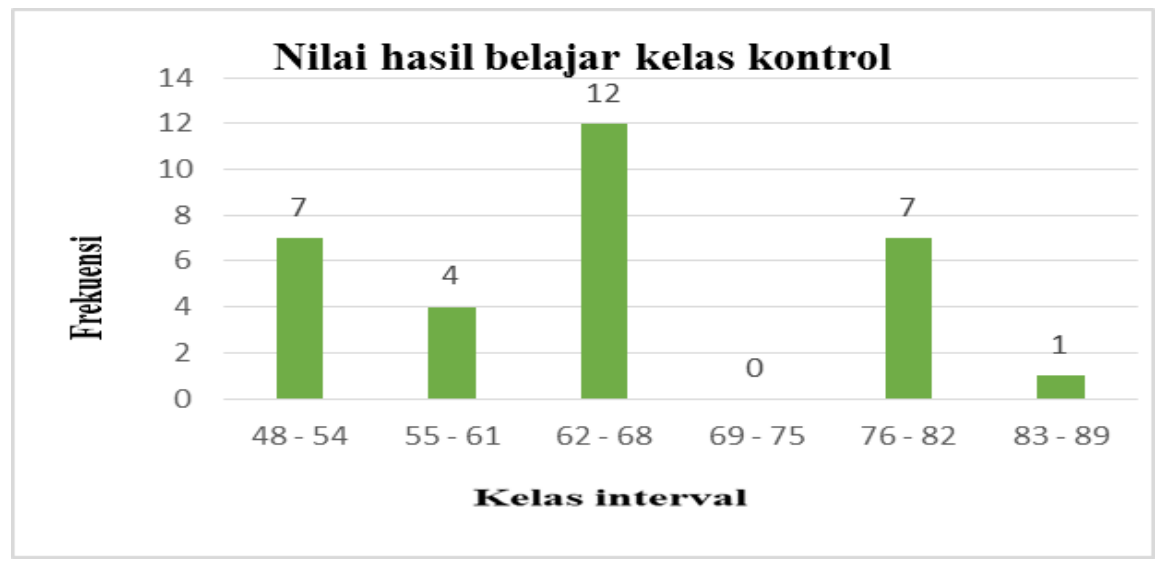

Gambar 3 Histogram Rata - Rata Hasil Belajar Siswa Kelas Kontrol

Berdasarkan gambar 3 menunjukan bahwa terdapat satu orang siswa yang memperoleh skor tertinggi pada rentang (83 - 89), sebanyak 7 siswa memperoleh skor hasil belajar pada rentang (76 - 82), sedangkan pada rentang 69 - 75 tidak terdapat siswa yang memperoleh skor hasil belajar, 12 siswa lainnya memperoleh skor hasil belajar pada rentang (62 - 68), 4 Orang siswa memperoleh skor hasil belajar pada rentang $(55-61)$ 
dan terdapat 7 orang siswa lainnya yang memperoleh skor terendah yaitu pada rentang $(52-58)$. Setelah mengamati kedua grafik distribusi frekuensi menunjukan bahwa nilai hasil belajar siswa kelas eksperimen yang menggunakan media permainan Teka-teki silang lebih tinggi dibandingkan dengan kelas control yang menggunakan media Power point.

\subsection{Pembahasan}

Penelitian mengenai hasil belajar siswa ini dilaksanakan di SMA Negeri 1 Marisa, Kec. Marisa, Kab. Pohuwato. Penetapan penelitian ini didasarkan pada pertimbangan bahwa penerapan media permainan teka teki silang kurang berkembang dengan baik sehingga perlu dikaji melalui penelitian ilmiah. Seperti yang telah dikemukakan pada bab sebelumnya yakni bab 1, bahwa rumusan permasalahan penelitian ini, yaitu apakah terdapat perbedaan hasil belajar geografi antara siswa yang diajar dengan menggunakan media permainan teka teki silang dengan siswa yang diajar menggunakan media power point. Sehingganya tujuan dari penelitian ini yaitu untuk mengetahui perbedaan hasil belajar geografi, yang menggunakan media permainan teka teki silang saat pembelajaran dibandingkan dengan siswa yang menggunakan media power point saat pembelajaran.

Tahap awal yaitu dengan melakukan observasi di sekolah serta berkonsultasi dengan salah satu guru geografi di sekolah untuk melakukan penelitian. Setelah semua itu dilakukan, terlebih dahulu peneliti melakukan sebuah proses validasi instrument untuk mengetahui tingkat kevalidan suatu test yang akan dicapai. Seperti yang telah diketahui bahwa validasi ini dilakukan dalam dua tahap yaitu validasi oleh dosen ahli dan melalui validasi empiric. Setelah dilakukan pengujian validitas didapatkan hasil yaitu dari 30 butir soal diuji cobakan ke 30 responden. 25 butir soal dinyatakan valid, sedangkan jumlah soal yang dinyatakan tidak valid sebanyak 5 soal. Oleh karena itu soal yang memenuhi kriteria valid dan mempunyai koefisien reliabilitas yang tes tinggi digunakan sebagai tes hasil belajar geografi baik pada kelompok eksperimen maupun pada kelompok pembanding. Berdasarkan pengujian realibilitas tes dengan menggunakan persamaan K-R 20 menunjukan bahwa $r_{\text {hitung }}>r_{\text {tabel }}$ yaitu $0,844>0,3610$, maka dapat disimpulkan bahwa instrument tersebut reliable dan dapat digunakan sebagai alat pengukuran tes hasil belajar.

Setelah diketahui bahwa tes yang akan digunakan sudah valid dan reliabel, selanjutnya adalah pelaksanaan perlakuan pada kedua kelas sampel yakni pada kelas X IPS 1 sebagai kelas eksperimen dan kelas X IPS 3 sebagai kelas kontrol, untuk materinya yaitu "Dinamika hidrosfer dan pengaruhnya terhadap kehidupan". Untuk kelas eksperimen diberikan perlakuan dengan menggunakan media berupa teka-teki silang

Pada pembelajaran di kelas eksperimen penguasaan materi untuk masing-masing siswa sangat baik dan mudah dipahami jika dibandingkan dengan kelas kontrol yang masih kurang baik, hal ini terjadi karena pada penerapan kelas eksperimen siswa diajak bermain sambil belajar menggunakan teka-teka silang, sehingga dengan menggunakan teka-teki silang sebagai pembelajaran, maka selain siswa termotivatasi untuk belajar juga memberi pemahaman terhadap kosakata yang mudah dan mendalam. Karena dalam teka-teki silang terdapat unsur permainan yang dapat menimbulkan kegairahan dan rasa senang dalam belajar tanpa harus berhadapan dengan situasi yang menjemukan. Hal ini didukung dari pendapat Ghannoe dalam Tesis Ermaita (2016) bahwa "Teka teki dapat bermanfaat di dalam proses pembelajaran,manfaatnya yaitu,dapat mengasah daya ingat, belajar klasifikasi, mengembangkan kemampuan analisa, menghibur, dan merangsang kreativitas. Sedangkan untuk kelas kontrol hanya belajar melalui penjelasan dari guru. Guru seringkali hanya menyampaikan materi pembelajaran berupa informasi kemudian siswa hanya mendengarkan dan mencatat penjelasan guru, sehingganya siswa kurang antusias dalam menerima materi yang disampaikan oleh guru dan menyebabkan penguasaan dalam pembelajaran siswa kurang. Setelah kelas eksperimen dan kelas kontrol mendapat perlakuan selanjutnya guru memberikan posttest berupa tes pilihan ganda yang terdiri dari 25 soal. Pemberian postest ini bertujuan untuk melihat perbedaan hasil belajar siswa yang menggunakan media berupa teka-teki silang dan hasil belajar siswa menggunakan media berupa power point.

Berdasarkan hasil analisis data diperoleh bahwa ada pengaruh yang positif terhadap hasil belajar siswa yang menggunakan media teka-teki silang dengan hasil belajar siswa yang diajar menggunakan media power point saat pembelajaran. Hal ini ditunjukan dari hasil uji t. Dari hasil penelitian diperoleh nilai $t$ yaitu $t_{\text {hitung }}=4,57$ dan $t_{\text {tabel }}=1.99$. Sampel dikatakan terdapat perbedaan yang signifikan apabila $t_{\text {hitung }}>t_{\text {tabel }}$. Hasil uji hipotesis menununjukan bahwa $t_{\text {hitung }}>t_{\text {tabel }}$ yaitu 4,57 $>1.99$, sehingga dapat simpulkan bahwa terdapat perbedaan yang signifikan antara hasil belajar siswa kelas eksperimen yang menggunakan media permainan teka-teki silang dengan hasil belajar siswa kelas control dengan menggunakan media power point. 
Terjadinya perbedaan hasil belajar ini salah satunya karena adanya penggunaan media permainan teka teki silang dalam pembelajaran kelas eksperimen. Hal ini sejalan dengan yang diungkapkan oleh Rani Fathonah (2013) bahwa :"Media permainan teka teki silang dapat memberikan kemudahan dalam memahami materi.

Teka-teki silang sebagai teknik pembelajaran kosakata tentu lebih menarik karena mengandung unsur permainan, hiburan dan dapat dilakukan secara santai dengan berbagai variasi. Dengan demikian, peserta didik termotivasi dan bergairah mempelajari kosakata yang dapat merangsang daya nalarnya untuk memahami materi,sehingga dapat mudah diingat dan menjadi pengetahuan yang sangat berkesan dan tidak mudah dilupakan sebagai sebuah pengalaman belajar. Akibatnya dapat memberi pemahaman terhadap materi secara mudah dan mendalam.

Berdasarkan penjelasan diatas dengan demikian hasil belajar siswa pada kelas eksperimen dengan menggunakan media permainan teka-teki silang lebih baik dari hasil belajar siswa kelas kontrol yang diajar dengan menggunakan media power point. Hal ini ditunjukan dari hasil uji t yaitu thitung > ttabel atau 4,57> 1.99, sehingga dapat simpulkan bahwa dari hasil uji t maka $\mathrm{H}_{0}$ ditolak dan $\mathrm{H}_{\mathrm{I}}$ diterima. Dengan kata lain terdapat perbedaan yang signifikan antara hasil belajar siswa yang diajar menggunakan media permainan Tekateki silang dengan hasil belajar siswa yang diajar dengan menggunakan media power point.

\section{Kesimpulan}

Berdasarkan hasil penelitian yang dilakukan, terdapat pengaruh yang positif terhadap hasil belajar siswa yang diajar menggunakan media permainan teka-teki silang dengan hasil belajar siswa yang diajar menggunakan media power point. Hal ini ditunjukan dari hasil uji t. Dari hasil penelitian diperoleh nilai t yaitu $\mathrm{t}_{\text {hitung }}=4,57$ dan $\mathrm{t}_{\text {tabel }}=1.99$. Sampel dikatakan terdapat perbedaan yang signifikan apabila $\mathrm{t}_{\text {hitung }}>\mathrm{t}_{\text {tabel }}$. Hasil uji hipotesis menununjukan bahwa $t_{\text {hitung }}>\mathrm{t}_{\text {tabel }}$ yaitu 4,57 $>1.99$, sehingga dapat simpulkan bahwa dari hasil uji t maka $\mathrm{H}_{0}$ ditolak dan $\mathrm{H}_{\mathrm{t}}$ diterima. Dengan kata lain terdapat perbedaan yang signifikan antara hasil belajar siswa yang diajar menggunakan media permainan teka-teki silang dengan hasil belajar siswa dengan menggunakan media power point.

\section{Ucapan Terima Kasih}

Penulis mengucapkan banyak terimakasih kepada Kepala Sekolah SMA Negeri 1 Marisa yang telah memberikan izin melakukan penelitian terhadap siswa. serta ucapan terimakasih yang sebesar-besarnya kepada Bapak dan Ibu Dosen Pembimbing yang telah memberikan arahan dan bimbingan sehingga segala hambatan dan kesulitan dapat peneliti selesaikan.

\section{Referensi}

Ermaita. (2016). Penggunaan Media Pembelajaran Crossword Puzzle Untik Meningkatkan Keterampilan Berpikir Kreatif Siswa di SMA Negeri 10 Bandar Lampung: Universitas Lampung.

Khalillah, M. (2012). Permainan Teka-Teki Silang sebagai Media dalam Pembelajaran Bahasa Arab (mufradat). Jurnal Pemikiran Islam. 37(1). 15-25.

Setiawan, R.I., Zuhdi, U. (2019). Pengaruh Media Teka-Teki Silang terhadap Hasil Belajar IPS Siswa

Kelas IV SDN Siwalankerto II Surabaya. JPGSD, 7(1). 2539-2548

Sugiyono. (2012). Metode Penelitian Kuantitatif, Kualitatif dan R\&D. Bandung: Alfabeta

Sumadoyo. (2013). Penelitian Tindakan Kelas. Graha Ilmu. Yogyakarta.

Somara, et all. (2013). Pengembangan Media Pembelajaran Dreamweaver Model Tutorial Pada Mata Pelajaran Mengelola Isi Halaman Web untuk Siswa Kelas XI Program Keahlian Multimedia di SMK Negeri 3 Singaraja, Jurnal Pendidikan Teknik Informatika (JANAPATI). Vol.1 No 2

Wasgito, M.A., Setiadarma, W. (2014). Pengembangan Media Permainan Edukatif Teka-Teki Silang (TTS) dalam Proses Pembelajaran Siswa Kelas VII SMP Negeri 2 Kalianget. Jurnal Pendidikan Seni Rupa. 2(3). 36-43

Witdawati, M. (2016). Perbandingan Penggunaan Media Video Pembelajaran dan Power Point Terhadap Hasil Belajar Geografi Kelas XI IPS di SMA N 16 Bandar Lampung Tahun Pelajaran 2015/2016. Universitas Lampung.

Zulfajrin, M., Amelia, R. (2016). Pengaruh Model Discovery Learning dengan Media Teka-Teki Silang terhadap Peningkatan Hasil Belajar Siswa pada Materi Sistem Koloid. Jurnal Edu Kimia, 1(1). 12-18. 